\title{
An Unusual Case of Metastatic Malignant Melanoma Presenting as Pseudomesothelioma with Intense Diffuse Pleural FDG Uptake Demonstrated on FDG PET/CT
}

\author{
FDG PET/BT'de Yoğun Diffüz Plevral FDG Tutulumu ile Birlikte Psödomezotelyoma \\ Şeklinde Kendini Gösteren Nadir Bir Metastatik Malign Melanom Olgusu
}

\author{
Robert Mansberg1,3, Rosamma Bency1, Chuong Bui1, Leo Ha1,3, Lucy Morgan2,3 \\ INepean Hospital, Department of PET and Nuclear Medicine, Penrith, Australia \\ 2Nepean Hospital, Department of Respiratory Medicine, Penrith, Australia \\ 3Sydney University, Faculty of Medicine, Nepean Clinical School, Sydney, Australia
}

\begin{abstract}
A 75-year-old male, non-smoker with history of asbestos exposure, and excision of $2 \mathrm{~mm}$ Clark IV cutaneous malignant melanoma 15 months earlier, presented with rapidly progressive dyspnea, left pleuritic chest pain, and weight loss. CT Pulmonary Angiography (CTPA) demonstrated bilateral pulmonary emboli and findings suspicious of mesothelioma. There was no evidence of infection or malignancy in the hemorrhagic pleural fluid aspirate. FDG PET-CT revealed extensive intense FDG uptake throughout the pleura of left hemi-thorax, bilateral hilar and mediastinal lymph nodes, bilateral adrenals and left gluteal musculature. Subsequent pleural biopsy was consistent with metastatic melanoma. The patient was referred for palliative therapy but died 10 days later.
\end{abstract}

Key words: Melanoma, pseudomesothelioma, radionuclide imaging

Conflicts of Interest: The authors reported no conflict of interest related to this article.

\section{Özet}

Yetmiş beş yaşında asbest maruziyeti ve 15 ay önce $2 \mathrm{~mm}$ Clark IV kutanöz malign melanoma eksizyonu öyküsü olan, sigara kullanmayan erkek hasta hızla ilerleyen nefes darlığı, sol yan ağrısı ve kilo kaybı ile başvurdu. BT Pulmoner Anjiografi'de (BTPA) bilateral pulmoner emboli ve mezotelyoma düşündüren bulgular saptandı. Hemorajik plevral sıvı aspiratında enfeksiyon veya malignite bulgusu yoktu. FDG PET-BT'de sol hemitoraks plevrası, iki taraflı hiler ve mediastinal lenf nodları, bilateral adrenal bezler ve sol gluteal kasta yoğun FDG tutulumu gösterildi. Plevra biyopsisi metastatik melanom ile uyumlu idi. Hasta palyatif tedavi için sevk edildi, ancak 10 gün sonra öldü.

Anahtar Kelimeler: Melanom, pseudomesothelioma, radyonüklid görüntüleme

Çıkar Çatışması: Yazarlar bu makale ile ilgili olarak herhangi bir çıkar çatışması bildirmemiştir.

Address for Correspondence: Robert Mansberg MD, Nepean Hospital, Department of PET and Nuclear Medicine, Penrith, Australia Phone: +61247342156 E-mail: mansberg@usyd.edu.au Received: 14.02.2013 Accepted: 25.07.2013 


\section{Introduction}

Malignant melanoma has the capacity to metastasize widely and quickly to every organ in the body, with pulmonary involvement occurring in almost all cases of generalized disease. The other common sites include liver, brain and bone (1). Metastatic malignant melanoma constitutes about $5 \%$ of all secondary malignancies of the lung. Systemic spread can be direct, lymphatic or hematogenous. The radiological patterns described in thoracic melanoma metastases include most commonly either multiple (40\%) or solitary (20\%) pulmonary nodules. Rare presentations in this group include a miliary pattern, mediastinal lymphadenopathy, pleural effusions, lytic bone lesions and extra-pleural mass (1).

\section{Case Report}

A 75-year-old male, non-smoker with history of asbestos exposure, presented with rapidly progressive dyspnea, left pleuritic chest pain, and weight loss. He had undergone excision of a $2 \mathrm{~mm}$ Clark IV cutaneous malignant melanoma from the right upper back 15 months previously. Lymphoscintigraphy and subsequent sentinel node lymphadenectomy did not demonstrate any lymph node involvement. Chest radiography at the time demonstrated pleural plaques but no other abnormality and no further staging was performed at the time. He was referred for a CTPA to assess for pulmonary emboli. The CTPA demonstrated bilateral pulmonary emboli, massive left pleural effusion with collapse of the left lung, bilateral calcified pleural plaques, left hilar and subcarinal lymphadenopathy and a left adrenal lesion (Figure 1). Subsequently the patient was referred for a FDG-PET/CT scan to assess for malignancy. Axial and Maximum Intensity Projection (MIP) images from whole-body FDG-PET/CT (64 slice Phillips TF Gemini, 1 hour post injection of $6.6 \mathrm{mCi}$ (245 $\mathrm{MBq}$ ) of F-18 FDG) demonstrated diffuse intense FDG uptake (SUVmax 14.1) throughout the pleura of the left hemi-thorax, bilateral hilar and mediastinal lymph nodes, bilateral adrenals and left gluteal musculature, highly suspicious of metastatic malignancy (Figure 2). As extensive, intensely FDG avid pleural disease in a patient with history of asbestos exposure and bilateral calcified pleural plaques is highly suggestive of mesothelioma, a provisional diagnosis of mesothelioma was made. Subsequent thoracoscopic pleural biopsy confirmed metastatic melanoma (Figure 3). The patient was referred for consideration of palliative therapy but died 10 days later. This case illustrates that other malignancies including metastatic melanoma can have a similar appearance as mesothelioma.

\section{Discussion}

Pleural effusion is an infrequent presentation of metastatic malignant melanoma $(1,2,3,4)$, with $70 \%$ of cases associated with solitary or multiple lung nodules. The literature on this topic is scarce. Impaired lymphatic drainage due to infiltrated mediastinal lymph nodes is the primary mechanism for accumulation of pleural fluid. The pleural site may have been reached through the lymphatics. Rarely, tumors can metastasize and spread diffusely within the pleura to form an encasing mass, which clinically and radiologically mimics malignant mesothelioma (5), the most frequent pathology being primary adenocarcinoma of the lung. Other tumors which grow diffusely within the pleura to simulate mesothelioma include

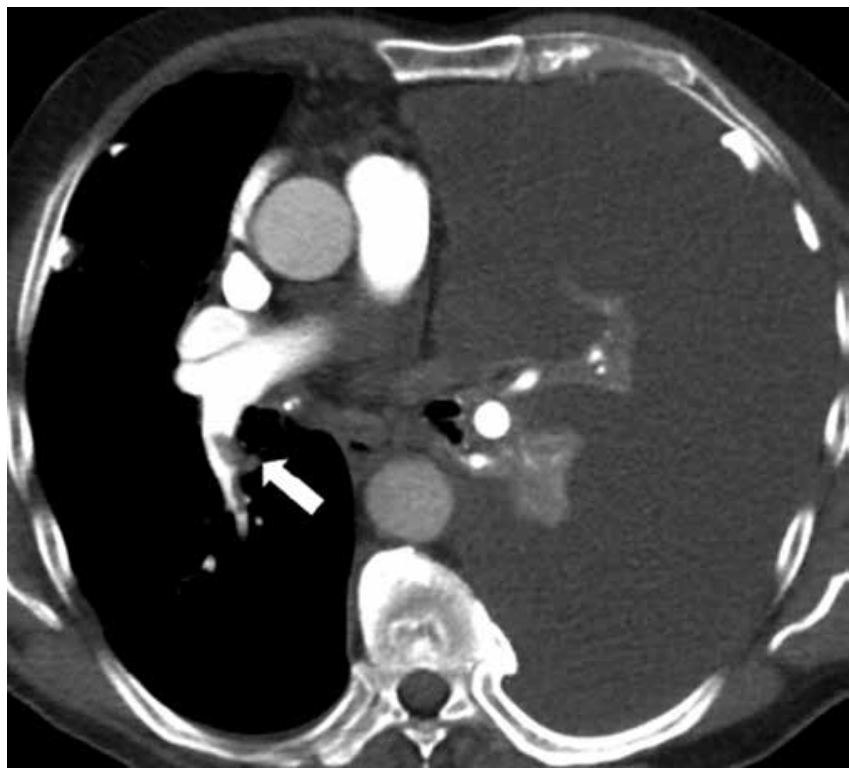

Figure 1. CTPA demonstrated bilateral pulmonary emboli (arrow showing right lower pulmonary artery embolus), massive left pleural effusion with collapse of the left lung and bilateral calcified pleural plaques
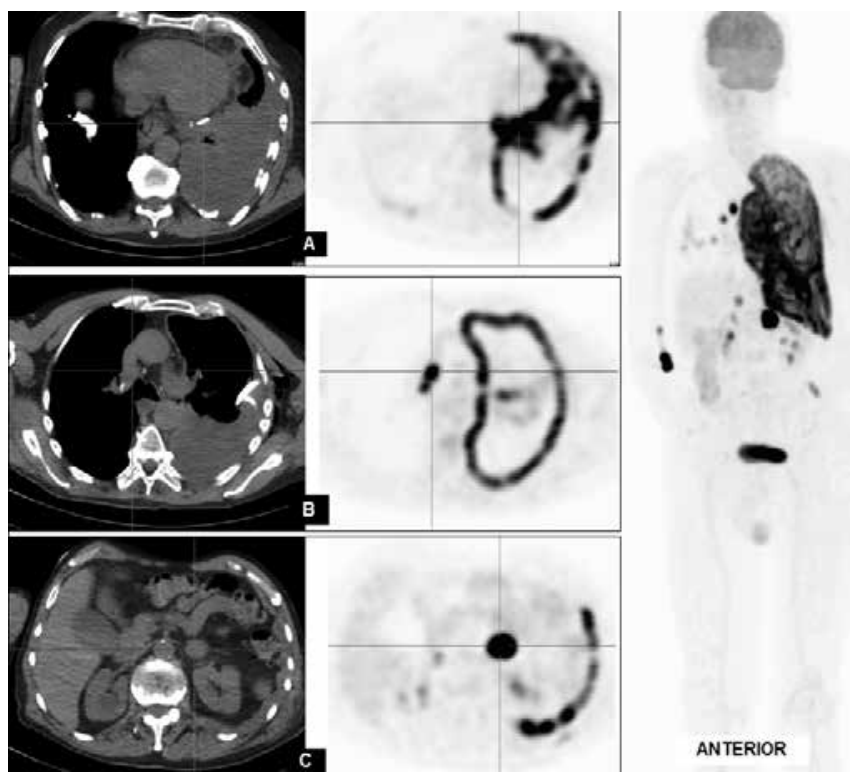

Figure 2. Axial and Maximum Intensity Projection images from whole-body FDG-PET-CT demonstrated diffuse intense FDG uptake throughout the pleura of the left hemi-thorax, bilateral hilar and mediastinal lymph nodes, bilateral adrenals and left gluteal musculature 
malignant vascular tumors, synovial sarcoma, thymoma and malignant lymphoma (5). The prognosis of malignant melanoma is variable with distant metastases sometimes occurring more than 10-years after initial therapy. The best prognostic indicators are tumor thickness and ulceration (5). The prognosis of pseudo-mesotheliomatous tumors is poor and is similar to mesotheliomas with the exception of malignant lymphomas and thymomas which show longer survival with appropriate treatment. The prognosis of "pseudo-mesotheliomatous" malignant melanoma is uncertain (5). Although malignant melanoma is typically FDG

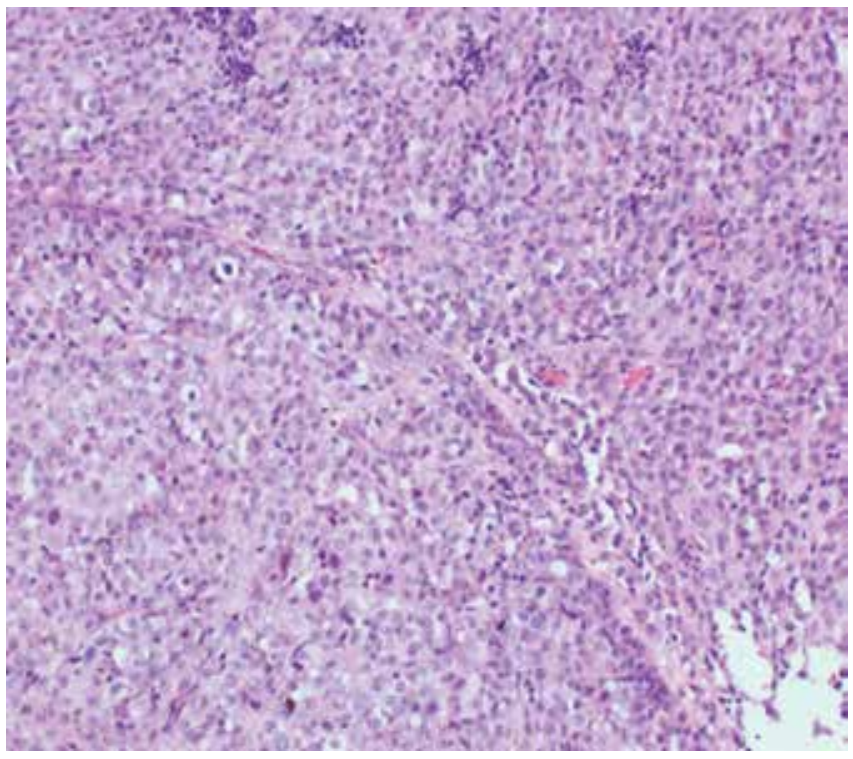

Figure 3A. Biopsy specimen showed tightly packed large malignant cells with increased mitotic activity and necrosis. Malignant cells strongly positive for HMB 45, S-100 and Melan A.

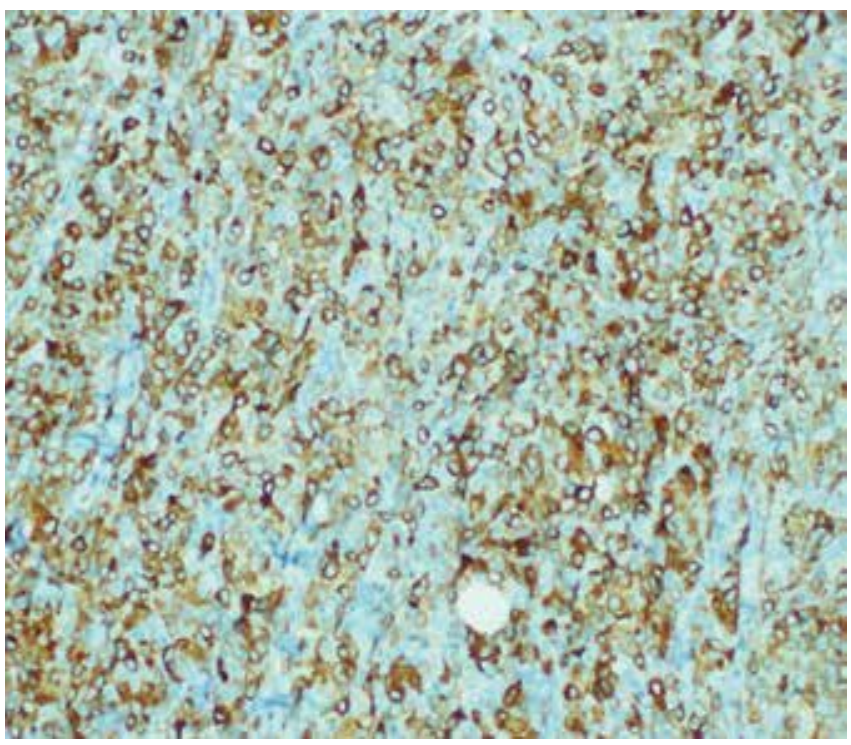

Figure 3B. Melan A stain demonstrating strongly positive malignant cells

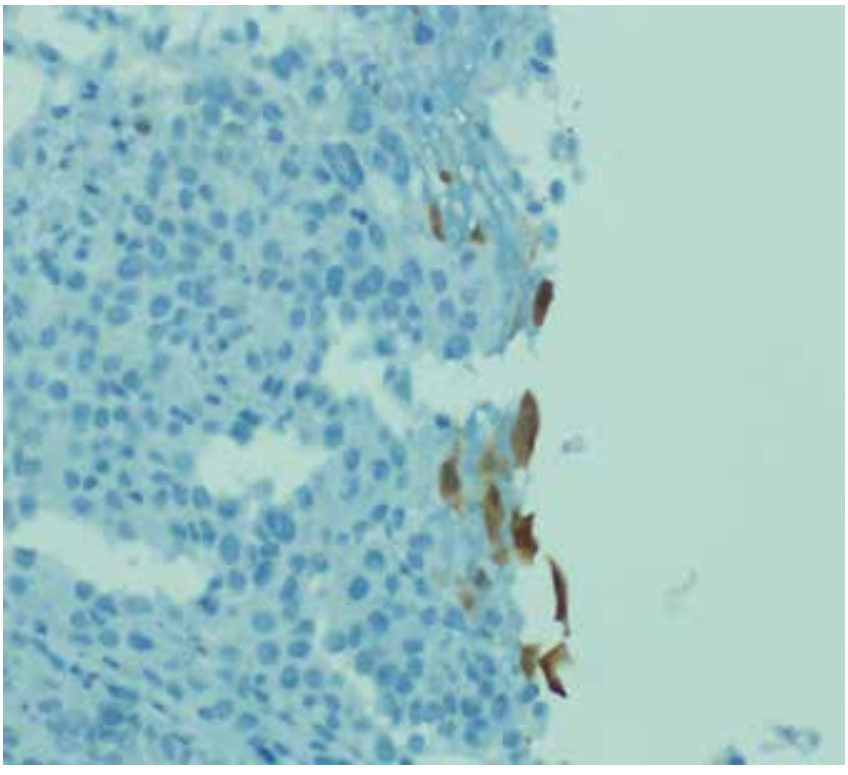

Figure 3C. Calretinin stain: Mesothelial cells positive and melanoma cells negative. Slides courtesy of Dr. Asokan Pasupathy

avid, the intense FDG uptake is nonspecific. The role of FDGPET in staging asymptomatic patients with stage 1 or stage 2 melanoma is limited. The vast majority of data in the literature suggests that FDG-PET is the most accurate imaging modality for identifying distant metastases in patients at high risk for harboring malignant lesions. FDG PET/CT is also an excellent tool to detect distant melanoma metastases and also allows quantification of FDG uptake using standardized uptake value, which may have prognostic implications $(6,7)$, as demonstrated in this patient who succumbed soon after the PET scan and only 10 days following the thoracoscopic pleural biopsy.

\section{References}

1. Chen JT, Dahmash NS, Ravin CE, Heaston DK, Putman CE, Seigler HF, Reed JC. Metastatic melanoma in the thorax: report of 130 patients. AJR. American Journal of Roentgenology 1981;137:293-298.

2. Kiser AC, Egan TM. Metastatic melanoma to the pleural space. Annals of Thoracic Surgery 2002;74:1257.

3. De Vita F, Giordano G, Fabozzi A, Guerrera B, Fabozzi T, Fasano M, Ferrara M, Fascione A, Di Benedetto G. Metastatic melanoma: an unusual presentation. Tumori 2011;97:130-132.

4. Nishiyama A, Yoshioka $\mathrm{H}$, Ishida T. Pleural metastases of malignant melanoma. Journal of Thoracic Oncology: Official Publication of the International Association for the Study of Lung Cancer 2010;5:905.

5. Luckraz H, Morgan M, Gibbs AR, Butchart EG. Pseudomesothelioma resulting from metastatic malignant melanoma. European Journal of Cardio-Thoracic Surgery 2005;28:655-656.

6. Makis W, Ciarallo A, Hickeson M, Rush C, Novales-Diaz JA, Derbekyan V, Laufer J, Stern J, Lisbona R. Spectrum of malignant pleural and pericardial disease on FDG PET/CT. AJR. American Journal of Roentgenology 2012;198:678-685.

7. Bastiaannet E, Hoekstra OS, de Jong JR, Brouwers AH, Suurmeijer $\mathrm{AJH}$, Hoekstra HJ. Prognostic value of the standardized uptake value for (18) F-fluorodeoxyglucose in patients with stage IIIB melanoma. European Journal of Nuclear Medicine \& Molecular Imaging 2012;39:1592-1598. 